\title{
No food, no drink, no noise
}

\author{
By Elaine Clement and Patricia A. Scott
}

\section{An eye-catching response to a universal problem}

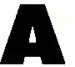
$\mathbf{s}$ is probably the case with most other academic libraries, the University Libraries at the Pennsylvania State University are confronted with problems generated by food, drink, and noise. Patrons bring to the library many different behavior patterns. Students who have come from high schools where the library was also the cafeteria or the detention hall are often not in the habit of leaving food or drinks and conversations outside the building. Our expectations of what their behavior should be is often at odds with reality.

At the University Park Campus, concerns voiced by staff and faculty led to the formation of a group to investigate the problem and suggest solutions. The group was made up of faculty and staff from public service areas in rare books, documents/maps, general reference, periodicals, the science branch libraries, and the undergraduate library (a 24-hour facility.)

\section{The campaign}

In January of 1991 the group was convened by the assistant to the dean for public information. As participants traded stories about noise levels in quiet study areas and pizza deliveries made to study carrels, it became apparent that all libraries were plagued by the same problems in varying degrees. A discussion of how staff in each of the branch libraries at University Park dealt with these problems revealed a lack of consistency among all the areas. Many staff were reluctant to confront student offenders without a university-endorsed code of conduct for the libraries. Staff members also felt uncomfortable about approaching coworkers who carry food and drink through the library during breaks or lunch.

At the end of

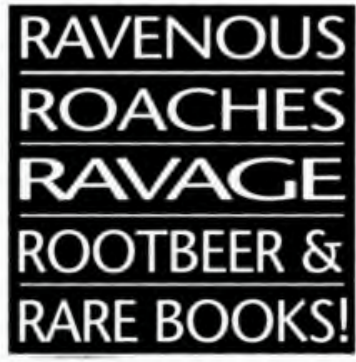
our first meeting we had reached two decisions: 1) we needed a written code of conduct for patrons and staff to follow, and 2) we needed to make an organized and concerted effort to publicize it. Thus was born our "campaign" to curb food, drink, and noise problems in the libraries.

Group opinion varied widely on what standards we should adopt and how they should be enforced. Despite this, during spring 1991 the group was able to reach consensus and drafted a food and noise policy. We began by searching library literature for articles about similar campaigns and examined the policies found in ALA's Spec Kit Number 144, Building Use Policies. We incorporated parts of these policies into our recommendations, adapting them to suit the needs of our institution.

\section{Getting students involved}

The group decided that eye-catching posters would be an effective way to educate students about the damage caused by the presence of food and drink and the disrup- tive effects of noise. We enlisted the help of a member of the graphic arts faculty, who allowed some of his students to use our campaign as a senior project. This idea of students 
designing for students appealed to the group because we felt it would have a greater impact on our primary audience.

The students designed posters, brochures, bookmarks, and buttons that used four graphics. Two graphics were aimed at noise control: one showed a picture of a lock and chain with the text "Laughing Learners Lock Your Lips!"; the other showed a clamp with the words "Clamorous Collegians Clamp Your Chops!" Both contained the tag line "Don't make noise in the library." Two graphics targeted food and drink problems. One showed a cockroach with the text "Ravenous Roaches Ravage Rootbeer and Rare Books!" The other showed a silverfish with the text "Salivating Silver-

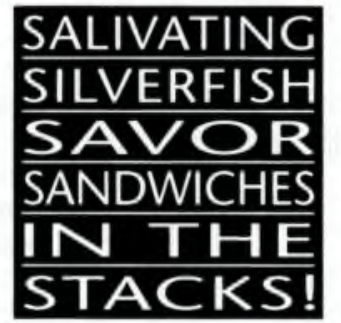

hibit from the Commission on Preservation and Access was installed in the public catalog room. By phasing in promotional materials we hoped to maintain interest in the campaign.

In spring 1993, the group reconvened to assess the campaign's impact. All agreed that the posters and other materials had helped to im- fish Savor Sandwiches in the Stacks!" Each contained the line "Don't eat or drink in the library."

In summer 1991, after presenting mock-ups of the posters at a session for library faculty and staff, the final draft of the "Food, Drink and Noise Policy" was submitted to the Libraries Academic Council.

In August, group members distributed posters and brochures to public service areas. The brochure stated the University Libraries' mission; explained how food, drink, and noise hinder our efforts; and gave costs for replacing damaged materials in a way which would be meaningful to students. For example, the money needed to repair five damaged library books is equivalent to the cost of twelve issues of Billboard, or 45 issues of Rolling Stone, or 60 issues of the Wall Street Journal.

\section{Printed publicity}

During fall 1991, the group conducted a publicity campaign to acquaint users and staff with the policy. Articles appeared in the student newspaper, the student orien-

tation guide, and in the university faculty and staff newsletter.

Bookmarks and buttons were not distributed to public service desks until Janu-

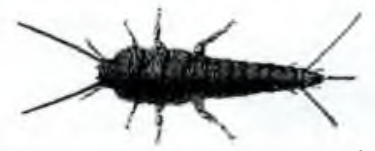

our policy made confronting offenders easier and more positive.

Some areas of the library reported little or no reduction in food, drink, and noise problems. As expected, student cooperation has been harder to achieve in areas with large study tables or where few staff members are visible.

Two years after its inception, the "University Libraries Code of Conduct" has been approved. Training for faculty and staff on what the code means and how staff will be expected to handle food, drink and noise problems was scheduled for summer 1993.

\section{Conclusion}

The No Food, No Drink, No Noise Group mounted a campaign to heighten awareness of problems in the library. Our goal was to try to alleviate the problems through humor and nonconfrontational means. In general, the group feels that the campaign was a success. A policy containing many specific recommendations for behavior was written and some of the suggestions were incorporated into a broad "University Libraries Code of Conduct," which is now in place. A marketing plan was devised to phase in each aspect of the campaign at timed intervals. Some of our ideas for publicizing our policy had to be dropped due to lack of funds (i.e., plastic bags printed with our logo), while others could not be implemented until a written code of conduct was approved (i.e., asking librarians to talk to students about the policy in orientation meetings and bibliographic instruction sessions). 
The graphic designs we used worked very well for brochures, bookmarks, and buttons, but were not effective for communicating our message on posters. The messages "Don't eat or drink in the library" and "Don't make noise in the library" appeared in small print at the bottom of the posters. The small print was intended to provoke interest and encourage the viewer to take a closer look. One reason that people were not drawn to read the small print may have been because of the height at which many posters had to be hung.

\section{Recommendations}

The group recommends the following actions to others who want to institute a similar campaign in their library:

1) Have a code of conduct in place before you begin the campaign. Both patrons and employees must know what is expected of them.

2) Closely examine the kinds of problems most common in your library and where they occur.

3) Devise a plan to sell your campaign. Calculate your costs and explore free sources of assistance. Check to see if a class can help.

4) Time the campaign so that things are in place at the beginning of the fall semester.

5) Be prepared to rethink your position on food, drink, and noise issues. Achieving group consensus requires some compromise.

6) Gain administrative and staff commitment to the campaign. Signs alone won't change behavior.

\section{(Indiana cont. from page 75)}

of the IU Department of Afro-American Studies. For more information call (812) 855-8547.

Although the aforementioned African American Studies collections are each housed in three different locations on the IU Bloomington campus, fundraising efforts are underway to build a new facility which could accommodate all three archives. About $\$ 2.5$ million in private donations must be raised to match state funding for the new building which will be named the Neal Marshall Black Culture Center. The new center is named after the first African American alumnus of IU, Marcellus Neal, 1895, and the first African American alumna of IU, Frances Marshall, 1919. To make a donation to the Neal Marshall Center, write to the IU Foundation, P.O. Box 500, Showalter House, Bloomington, IN 47402, or call (812) 855-8311.

\section{(Censorship cont. from page 78)}

heightened awareness of the importance of preparation for a censorship challenge. The whole process took one and a half months, but it seemed to drag out longer, perhaps prolonged by a sense of insecurity or not knowing what to expect next.

Censorship incidents can take a tremendous toll on a community, as evidenced in Cumberland County, North Carolina, where the presence of Daddy's Roommate and Heather Has Two Mommies (Alyson, 1989) on library shelves has delayed the construction of five library branches. ${ }^{2}$ As academic librarians we hadn't been lulled into complacency, but nonetheless were surprised when it happened to us. The groundwork of the past (the library's "Collection Policy Statement," and the affirmation of the concept of intellectual freedom) proved to be invaluable. Six months after we received the initial letter of complaint, we are in the midst of revising and updating our collection development statement. This experience will make us examine more closely the section on censorship and intellectual freedom, so routinely included in collection development policies, but never really expected to be used.

\section{Notes}

"Mary Jo Godwin, "Conservative Groups Continue Their Fight to Ban Daddy's Roommate," American Libraries 23 (December 1992): 968.

${ }^{2}$ Michael J. Sadowski, "Book Controversy Delays New Branches," Scbool Library Journal 39 (May 1993): 12.

(Letters cont. from page 80)

ography, medieval French philology as well as medieval French philological bibliography. Why should a university bother to hire faculty in medieval French philology, or in chemistry, or in philosophy, if its librarians can teach and perform worldly research in these and all other subjects (as McKinzie seems to claim)?

What librarians teach is (best called) BI, or (a bit less well called) documentation, or (even less well called) library skills. But to teach research simpliciter, of both kinds and in all subjects-such a suggestion is on the face of it unaware both of what such researchers $d o$ and of the meaning of the words with which we describe them and their products. $-J . M$. Perreault, bead of special collections, the University of Alabama in Huntsville 